УДК 821.111-311.3.091Стивен7Острів+821.161.2-311.3.091Рутків7Джури

DOI https://doi.org/10.52726/as.humanities/2021.3.3

\author{
А. М. ГАЛЕНКО \\ старший викладач кафедри украӥнської філології та журналістики, \\ Східноукрайнський національний університет імені Володимира Даля, \\ м. Сєвєродонеиьк, Луганська область, Украӥна \\ Електронна пошта: galenko.anna.m@gmail.com \\ https://orcid.org/0000-0002-4997-0599
}

\title{
КОМПАРАТИВНИЙ АНАЛІЗ ХРОНОТОПУ ДОРОГИ В ПРИГОДНИЦЬКИХ РОМАНАХ СВІТОВОЇ ЛІТЕРАТУРИ (НА ПРИКЛАДІ ТВОРІВ «ОСТРІВ СКАРБІВ» ТА «ДЖУРИ КОЗАКА ШВАЙКИ»)
}

У статті проаналізовано хронотоп дороги як один із найпоширеніших форм часопростору у пригодницькому романі. Увагу приділено творам «Джури козака Швайки» Володимира Рутківського та «Острів скарбів» Роберта Луїса Стівенсона. Були проаналізовані головні герої-діти в пригодницьких романах Р. Стівенсона та В. Рутківського з метою визначення особливих рис теми дорослішання і переходу з дитинства у дорослість, у самостійність. Характерологічну роль відіграє бажання подорожей та легкість, з якою хлопці в обох творах вирушають у дорогу. Визначено, що головні герої Санько та Грицик в українському романі, а також Джим в англійському проходять випробування у подорожі і так переходять у дорослий етап життя. Ключовим у зображенні цих перетворень постає хронотоп дороги. Так само, як і в історичному пригодницькому романі Володимира Рутківського, відбувається формування ідентичності Джима в авантюрно-пригодницькому романі Роберта Стівенсона «Острів скарбів». Джим дорослішає, мужніє після подорожі, знаходить справжній скарб і здобуває визнання у суспільстві. У романі Роберта Стівенсона синтезовано традиції морського пригодницького роману і проблеми етичного плану, перенесено цивілізаційний конфлікт із простору традиційної Англії на острів, де відсутні будь-які соціокультурні норми. Джим Хокінс як благородний хлопчина проходить через низку випробувань, втрат і розчарувань, що $\epsilon$ досить знаковою рисою неоромантичного героя. Вагомим $є$ те, що попри мотив подорожі - пошук скарбів головний герой чітко розмежовує матеріальні та духовні цінності. Долаючи перешкоди, що трапляються на шляху до винагороди, тобто скарбу, хлопець набуває досвіду, що дає можливість розкрити такі його риси, як честь, відважність та гуманізм. Згуртовані однією метою, персонажі різних поколінь змогли дати гідну відсіч ворогові - як татарам козаки з джурами, так і піратам моряцька команда. У результаті аналізу зроблено висновок, що хронотоп дороги виконує в романі сюжетотвірну, характерологічну, онтологічну й символічну функції й допомагає розкрити головну думку твору та зобразити ключові образи.

Ключові слова: світова література, літературознавство, хронотоп дороги, метафоризація, дитяча література, мотив дорослішання.

Постановка проблеми. Однією 3 найпоширеніших форм часопростору, що описується у пригодницькому романі, є хронотоп дороги. Відомий дослідник М. Бахтін, який в основу культурної типології вкладає ідею хронотопу, пов'язуючи простір і час 3 типом особистості, стверджує: «Значення хронотопу дороги в літературі величезне: рідкісний твір обходиться без будь-яких варіацій мотиву дороги, а багато творів прямо побудовані на хронотопі дороги і дорожніх зустрічей та пригод» [Бахтін 1975 : 248]. Цей тип часопросторових відношень актуалізується у літературно-художньому творі, передаючи ідею поступального руху 3 минулого в майбутнє, переходу з одного стану в інший. Так, дорога виступає метафорою життєвого шляху, нерозривного з подіями зустрічі і розлуки, втечі, переховування, знаходження нового та втрати прихистку тощо.

Аналіз попередніх досліджень. Існують дослідження хронотопу у літературно-художньому творі М. Бахтіна, Ю. Лотмана, В. Топорова, І. Меркулової, Л. Ноздріної, П. Повалко та ін. Творчість В. Рутківського стала об'єктом досліджень таких науковців: О. Гаврош, У. Баран, Н. Марченко. Зокрема, Л. Романенко розглянула образ козака-характерника в тетралогії «Джури» [Романенко 2015], М. Васильєва проаналізувала філософське наповнення історичних подій у цих творах [Васильєва 2018]. До аналізу творчості Р. Стівенсона зверталися як зарубіжні, так і вітчизняні літературознавці. Р. Олдінгтон, Н. Я. Дьяконова проаналізували життєвий і творчий шлях письменника. 
Про хронотоп острова згадується у роботі «Ігрова парадигма англійського роману останньої третини XX ст.» Ю. Шуби [Шуба]. Проте актуальною є проблема компаративного аналізу творів української та світової літератури.

Мета статті - дослідити особливості хронотопу дороги у пригодницьких романах «Острів скарбів» та «Джури козака Швайки», порівняти ïx функції у творах, провести компаративний аналіз значення хронотопу дороги у становленні особистостей головних героїв.

Виклад основного матеріалу. Обидва твори можна віднести до дитячої пригодницької літератури, де йдеться про пригоди та дорослішання через подорожування юних хлопців. Варто згадати, що в дитячій літературі дитинство переважно осмислюється як цінний внутрішній всесвіт, що для дорослих є забутим, незбагненним і водночас захопливим. Натомість дорослість у дитячих творах трактується як пора, що втратила безпосередність і чистоту. У світовій літературі утвердився об'ємний і багатогранний образ дитинства. Проникаючи у внутрішній світ дитини, змальовуючи складність i глибину характеру героя, письменники відкривають джерела розвитку людства у внутрішньому світі дитини, показуючи, як формується особистість у протистоянні світлих і темних сторін, у сприйнятті радості й горя реального світу, його гармонії та суперечностей.

Функція дороги у творі В. Рутківського полягає у метафоризації життєвого шляху головних героїв і становлення їх ідентичності. Ця функція розширюється, зрештою, до метафоризації історичного шляху становлення України, вибору вектору історичного руху. Це розкриває символічну функцію часопростору в романі. Автор вибудовує просторово-часову перспективу, де час людського життя входить у історичний час.

Герої обох творів на початку мріють про пригоди і в результаті отримують їх сповна.

Типовими i водночас дуже незвичними $\epsilon$ образи головних героїв роману «Джури козака Швайки» Грицика і Санька. У пригодницькому романі Рутківського хронотоп дороги відіграє сюжетотвірну роль: увесь твір побудований на мандрівці хлопчаків. На самому початку твору хлопці змушені втікати 3 рідного села. Проте початок дороги начебто пов'язаний 3 таким прагматичним бажанням запобігти власній смерті, адже вони змушені утікати від гніву пана Кобильського за їхню витівку.

Так само відбувається формування ідентичності Джима в авантюрно-пригодницькому романі Стівенсона «Острів скарбів». Від самого початку твору він змушений утікати з рідного дому, аби урятуватись від піратів. Так, він вирушає на пошуки скарбу, але перш за все хлопець тікає, бо на нього полюють пірати, аби відібрати у нього карту острова скарбів.

Джим легко вирішує йти назустріч пригодам, однак на хвилинку зупиняється, зрозумівши, напевне, що він прощається 3 домом, $з$ рідними місцями, з матір'ю та іiї опікою й підтримкою. Можна сказати, що він прощається здитинством, тобто так починається його перехід у доросле життя: «Ніч минула, і наступного дня, пообідавши, ми з Редрутом знову вийшли на дорогу. Я попрощався 3 матір'ю, $з$ бухтою, біля якої народився, $з$ любою давньою вивіскою «Адмірал Бенбов», хоч, пофарбована, вона вже не здавалася мені такою дорогою... Та от ми завернули за ріг, і мій дім зник з очей» [Стівенсон].

Втрата дому як елемент сюжету твору прослідковується у головних героїв «Джур»: Санько змушений прощатися 3 домом, 3 яким асоціюється затишок, обжитість, захищеність, тобто те, що М. Еліаде називає ідеальним Всесвітом облаштованим, освоєним, своїм [Еліаде]. Грицик, хоч і $є$ сиротою, але теж втрачає узвичаєний побут, бо до цього моменту він жив по черзі в усіх воронівців, бо «ні хати, ні матері з батьком не лишилося. Ще з позаминулої осені, коли зненацька наскочили татари <...> [Рутківський].

Герої втрачають свій дім, тому вони змушені шукати собі новий світ, нову онтологічну субстанцію, аби не розчинитися в хаосі.

I новий шлях герої обирають невипадково. Ще коли вперше читач зустрічається з персонажами, вони спостерігають за майбутніми козаками, що можна потрактувати як обряд їхньої ініціації: «У Воронівці так повелося здавна: як тільки висівали в землю зерно, найметкіші хлопці збивалися у ватагу і йшли у дніпровські плавні полювати на звіра чи ловити рибу. Раніше це називалося здобичництвом. А тепер, хоча хлопці займаються все тим же, чомусь називається козакуванням» [Рутківський 2016 : 14]. Козакування постає як спосіб формування кмітливості, сміливості, витривалості й фізичної 
сили молодиків. У такий спосіб хлопчаки переходять у стан підліткового дорослішання, коли треба вибирати свій життєвий шлях, визначатися з подальшою долею.

У романі Р. Стівенсона моментом ініціації $\epsilon$ знайомство зі старим мореплавцем, якого сам хлопець називає капітаном. Далі Джим стає на шлях морськихпригод, долучаєтьсядоспільноти моряків, що теж вимагає формування витривалості, сили, мужності, впевненості та моральної стійкості. Автор вводить у твір моряків і морську подорож як певний приклад звитяги, наполегливої праці, подолання труднощів.

Герой англійського пригодницького роману теж постає перед нами на початку в невеличкій бухті, де, знайомлячись зі старим суворим капітаном, якого усі боялися, стає його товаришем. Мовчазний Білл намагається уникати людей, адже йому є що приховувати, єдиним, кому він довірився, є хлопець, який і виступає розповідачем у романі: «Для мене принаймні тут не було ніякої таємниці, бо я став, так би мовити, співучасником його тривог» [Стівенсон]. Тут уже виявляються незвичні здібності хлопця. Далі він демонструє неабияку кмітливість та здогадливість, коли знаходить карту острова скарбів і рятує саме іiі, а не обирає гроші. Недарма тут хлопчик робить вперше вибір на користь чогось більшого, ніж просто матеріальні цінності: він намагається певним чином врятувати те, що було найдорожчим для моряка, який був постояльцем у його будинку, тобто продовжити справу товариша після його смерті.

Саньку й Грицику нудно вже вдома в селі, адже в них $є$ непересічні таланти, про що ми довідуємося ще на початку твору: Санько має таємну здатність «подумки віддавати накази й прохання» [Рутківський $2016: 13$ ], а Грицик знає все про всіх, бо йому завжди «треба кудись бігти, щось розізнавати» [Рутківський 2016 : 14]. Обидва хлопці в селі займаються не своєю справою: Санько випробовує свій дар передбачень на курчатах, а Грицик нудиться, випасаючи сільську череду.

I тут єдиним виходом для самореалізації стає зміна локації через введення хронотопу дороги задля удосконалення особистості, розвитку вроджених задатків. Саме в дорозі хлопці знаходять собі старших, тобто тих, що мають досвід, наставників: діда Кудьму для розви- тку ворожбитських навичок та Швайку - майстра козацької справи. Ці дорослі допомагають дітям усвідомити їхню унікальність, їхнє місце у світі, їхню приналежність до певної спільноти, тобто сформувати їхню ідентичність.

У Джима теж можемо побачити наставниківдорослих. Це доктор Лівсі, який постає перед нами як суддя, джентльмен, чоловік неймовірної хоробрості, самовідданий лікар та сумлінний громадянин, готовий без вагань виконати свій професійний і людський обов'язок. Також це сквайр Трелоні, чудовий стрілок, досвідчений мандрівник, кращий в команді трьох дисциплінованих і вірних слуг. Він стає спонсором та організатором усієї подорожі на острів, проте цей персонаж не може втримати лідерство іпередає командування кораблем капітану Смоллету.

У творах реалізується загальнолюдська тема важливості зв'язку поколінь задля загальної справи та продовження життя людства в гуманістичному суспільстві. Згуртовані однією метою, персонажі різних поколінь змогли дати гідну відсіч ворогові - як татарам козаки з джурами, так і піратам моряцька команда.

Крім метафоризації хронотопу дороги як життєвої долі головних героїв, в українському романі спостерігаємо перенесення часопростору дороги на інший смисловий рівень - рівень історичного шляху України, яка вступає в новий історичний період - добу, коли провідною верствою населення стає козацтво. Автор вибудовує просторово-часову перспективу, де час людського життя увіходить у час історичний.

Джим Хокінс як благородний хлопчина проходить через низку випробувань, втрат і розчарувань, що є досить знаковою рисою неоромантичного героя. Вагомим $\epsilon$ те, що, попри мотив подорожі - пошук скарбів, головний герой чітко розмежовує матеріальні та духовні цінності. Саме духовність, людяність є дороговказом у його житті. Це людина, що завжди стає на бік правди, завжди лишається на світлій стороні, попри зваби оточення. Подорож для хлопчини - це випробовування особистості, сформованості характеру. Так, навіть у середовищі піратів Джим залишається високоморальною людиною, не сходить зі шляху гуманізму. Від самого початку він постає як благочестивий та відважний хлопець і не втрачає цих рис після усіх випробувань долі. 
Роберт Стівенсон намагається синтезувати традиції морського пригодницького роману і проблеми етичного плану, переносячи цивілізаційний конфлікт із простору традиційної Англії на острів, де відсутні будь-які соціокультурні норми.

Час у англомовному романі накладається на такі локуси, як море, берег, острів. На березі відбувається зав'язка усіх подій, планування подорожі, збір команди. У морі розкривається перед ключовим героєм правда про заколот на кораблі. Тут з'являється моральний вибір: прийняти сторону піратів чи рятувати усіма силами офіційних керманичів корабля як світлу сторону суспільства. Недарма автор вибирає локацією саме острів, адже на відмежованому від цивілізації та обмеженому берегами й морем просторі найкраще виявляється внутрішня сутність особистості. На людину не діють закони Англії чи інших держав, тут немає якогось захисту, обмежень прав. Особистість робить свій вибір, опираючись тільки на власну внутрішню сутність. Навіть потрапивши на острів, де не діють закони Англії та якість моральні чи культурні норми, попри загрозу життю, Джим робить вибір на користь своїх гуманістичних моральних цінностей. У цьому прослідковується антропоцентрична риса хронотопу дороги.

Саме умови подорожі новими місцями дозволяють виявитись тим рисам хлопців, які, можливо, так би й лишились прихованими у звичних повсякденних умовах 3 дитинства обжитого середовища. Так, хронотоп дороги виступає сюжетотвірним стрижнем романів.

Варто зазначити, що такий типовий для англомовної літератури локус, як острів, стає ідеальним місцем для перевірки сформованості нової особистості хлопця, стійкості його моральних переконань, його дорослості. Море тут виступає як стихія піратів, де вони відчувають себе як вдома.

Таким локусом в українському аналізованому романі виступають плавні, адже саме там відбуваються ключові сюжетотвірні події, що впливають на визначення стійкості й дорослості особистості головних героїв-юнаків.

Санько й Грицик тут мають риси казкових героїв - сміливих, відчайдушних, сильних, які, подолавши усі випробування, повертаються в початкову локацію переможцями, отримують нагороду. 3 одного боку, вони знаходять своє покликання в житті, дорослішають, а з іншого боку, вони змінюють соціальне становище - 3 хлопців, яких ніхто не сприймав серйозно у селі, на козацьких джур, якими захоплюються дівчата та про яких схвально відгукуються козаки.

Подібних рис набуває головний герой англійського роману Джим. Він і дорослішає, мужніє після подорожі, і здобуває визнання, i знаходить справжній скарб: «Кожен із нас одержав свою частку скарбу й скористався нею - розумно чи по-дурному - на власний розсуд» [Стівенсон]. Хлопець повертається додому уже досвідченим, розумним та багатим. Він розуміє, що ніякі пригоди й скарби не вартують втрати спокійного життя: «Решта скарбів - бруски срібла і зброя - все ще лежать там, де Флінт закопав їх $\mathrm{i}$, коли хочете знати мою думку, їм там і місце. А мене вже ні волами, ні арканом не заманиш удруге на оцей клятий острів» [Стівенсон].

Висновки. Отже, проаналізувавши особливості хронотопу дороги у авантюрно-пригодницькому романі Р. Стівенсона «Острів скарбів» та історичному пригодницькому романі В. Рутківського «Джури козака Швайки», ми визначили, що дорога відіграє ключову роль в особистісному формуванні юнаків. На основі аналізу образів головних героїв-дітей прослідковуються особливі риси теми дорослішання і переходу 3 дитинства у дорослість, самостійність. У формуванні художнього мікросвіту провідну роль відіграє хронотоп, котрий виконує у творі онтологічну, антропоцентричну, символічну, сюжетотвірну, естетичну й прагматичну функції. Перспективи подальших досліджень вбачаємо в аналізі ключових сюжетотвірних концептів роману «Острів скарбів» Роберта Стівенсона. 


\section{ЛІТЕРАТУРА}

1. Бахтин М. М. Вопросы литературы и эстетики. Исследования разных лет. Москва : Художественная литература, 1975. $504 \mathrm{c}$.

2. Васильєва М. В. Філософське осмислення історичних подій у трилогії В. Рутківського «Джури козака Швайки». Література й історія : матеріали Всеукраїнської наукової конференції, м. Запоріжжя, 11-12 жовтня 2018 р. / редкол. : Н. В. Горбач (відп. ред.), В. М. Ніколаєнко (ред.-упоряд.), І. М. Бакаленко (техн. ред.) та ін. Запоріжжя : Запорізький національний університет, 2018. С. 34-36.

3. Романенко Л. В. Художня трансформація образу козака-характерника в трилогії Володимира Рутківського «Джури». Науковий вісник Міжнародного гуманітарного університету. Серія «Філологія». 2015. № 16. С. 40-42.

4. Рутківський В. Джури козака Швайки : роман. 1-ша книга трилогії «Джури» / мал. М. Паленка. Київ : А-БАБА-ГА-ЛА-МА-ГА, 2016. $326 \mathrm{c.}$

5. Стівенсон Р. Л. Острів скарбів / пер. з англ. Ю. Корецький ; зібрання творів у 5-ти томах. Том 1. Київ : Українознавство, 1994. 384 с. С. 7-169. URL: https://ae-lib.org.ua/texts/stevenson_treasure_island_ua.htm.

6. Элиаде М. Избранные сочинения. Миф о вечном возвращении. Образы и символы. Священное и мирское. Москва : Ладомир, 2000. 414 с.

7. Шуба Ю. Ігрова парадигма англійського роману останньої третини XX ст. : автореф. дис. ... канд. філол. наук : 10.01.04. Сімферополь, 2011. 20 с.

\section{REFERENCES}

1. Bahtin M. M. (1975). Voprosyi literaturyi i estetiki. Issledovaniya raznyih let. [Questions of literature and aesthetics. Studies of different years] Moscow: Hudozhestvennaya literature. 504 p. (in Russian).

2. Vasylieva M. V. (2018). Filosofske osmyslennia istorychnykh podii u trylohii V. Rutkivskoho "Dzhury kozaka Shvaiky". [Philosophical comprehension of historical events in V. Rutkivsky's trilogy "Jury of the Cossack Shvaika"]. Literature and history: materials of the All-Ukrainian scientific conference (11-12 zhovtnia 2018 r.) / redkol. : N. V. Horbach, V. M. Nikolaienko, I. M. Bakalenko ta in. Zaporizhzhia: Zaporizkyi natsionalnyi universytet. Pp. 34-36. (in Ukrainian).

3. Romanenko L. V. (2015). Khudozhnia transformatsiia obrazu kozaka-kharakternyka v trylohii Volodymyra Rutkivskoho "Dzhury". [Artistic transformation of a Cossack-characterist image in Volodymyr Rutkivsky's trilogy "Jury"]. Scientific Bulletin of the International Humanities University. Vol.: Filolohiia. № 16. Pp. 40-42. (in Ukrainian).

4. Rutkivskyi V. (2016). Dzhury kozaka Shvaiky: roman. 1-sha knyha trylohii "Dzhury" / mal. M. Palenka. [Jury of the Cossack Shvaika: a novel. 1st book of the trilogy "Jury"] Kyiv : A-BA-BA-HA-LA-MA-HA, 326 p. (in Ukrainian).

5. Stevenson R. L., (1994). Ostriv skarbiv [Treasure Island]. Yu.Koretskyi (translated from English) / Collection of works in 5 volumes. Volume 1. K. : Ukrainoznavstvo, 384 p. - P.: 7-169. Retrieved from: https://ae-lib.org.ua/texts/stevenson_treasure island_ua.htm. (accessed 2 December 2021).

6. Eliade M. (2000). Izbrannyie sochineniya. Mif o vechnom vozvraschenii. Obrazyi i simvolyi. Svyaschennoe i mirskoe [Selected works. The myth of eternal return. Images and symbols. Sacred and worldly]. Moscow : Ladomir, $414 \mathrm{p}$. (in Russian).

7. Shuba Yu. (2011). Ihrova paradyhma anhliiskoho romanu ostannoi tretyny XX st. : [Game paradigm of the English novel of the last third of the twentieth century]. : authoref. dis. ... cand. philol. Science : 10.01.04. Simferopol, 20 p. (in Ukrainian). 


\section{A. M. GALENKO}

Senior Lecturer at the Department of Ukrainian Philology and Journalism, Volodymyr Dahl East Ukrainian National University, Severodonetsk, Luhansk region, Ukraine

E-mail: galenko.anna.m@gmail.com

https://orcid.org/0000-0002-4997-0599

\section{COMPARATIVE ANALYSIS OF THE CHRONOTOPE OF THE ROAD IN ADVENTURE NOVELS OF WORLD LITERATURE (ON THE EXAMPLE OF THE WORKS "TREASURE ISLAND" AND "DZHURAS OF COSSACK SHVAIKA")}

The article analyzes chronotope of road as one of the most common forms of time and space in an adventure novel. Attention is paid to the works "Dzhuras of Cossack Shvaika" by Volodymyr Rutkivsky and "Treasure Island" by Robert Louis Stevenson. The main characters-children in the adventure novels by R. Stevenson and V. Rutkivsky were analyzed in order to determine the special features of the theme of growing up and the transition from childhood to adulthood, to the independence. The desire to travel and the ease with which the boys in both works go on the road play a characteristic role. It is determined that the main characters Sanko and Hrytsyk in the Ukrainian novel, as well as Jim in the English are tested in the journey and thus enter the adult stage of life and the key in the depiction of these transformations is the chronotope of the road. Just as in Vladimir Rutnitsky's historical adventure novel, Jim's identity is being formed in Robert Stevenson's adventure novel Treasure Island. Jim grows up, becomes courageous after the journey, finds a real treasure and gains recognition in society. Robert Stevenson's novel synthesizes the traditions of the sea adventure novel and the problems of the ethical plan, transfers the civilizational conflict from the space of traditional England to an island where there are no socio-cultural norms. Jim Hawkins as a noble boy goes through a series of trials, losses and disappointments, which is quite a hallmark of the neo-romantic hero. It is important that despite motive of the journey - the search for treasure - protagonist clearly distinguishes between material and spiritual values. Overcoming obstacles in the way of reward, like treasure, the boy gains experience that allows him to reveal such traits as piety, courage and humanism. United for one purpose, the characters of different generations were able to repel the enemy: both Cossacks with the Jury to Tatars, and the same the sailors team to the pirates. As a result of the analysis, it was concluded that the chronotope of the road performs plot-forming, characterological, ontological and symbolic functions in the novel and helps to reveal the main idea of the work and depict key images.

Key words: world literature, literary studies, chronotope of the road, metaphorization, children's literature, motive of growing up. 